\title{
Intragenomic variation in the second internal transcribed spacer of the ribosomal DNA of species of the genera Culex and Lutzia (Diptera: Culicidae)
}

\author{
Fabiana Tavares Vesgueiro', Bruna Demari-Silva', Rosely dos Santos Malafronte ${ }^{2}$, \\ Maria Anice Mureb Sallum', Mauro Toledo Marrelli+ \\ ${ }^{1}$ Departamento de Epidemiologia, Faculdade de Saúde Pública ${ }^{2}$ Instituto de Medicina Tropical de São Paulo, \\ Universidade de São Paulo, São Paulo, SP, Brasil
}

Culex is the largest genus of Culicini and includes vectors of several arboviruses and filarial worms. Many species of Culex are morphologically similar, which makes their identification difficult, particularly when using female specimens. To aid evolutionary studies and species distinction, molecular techniques are often used. Sequences of the second internal transcribed spacer (ITS2) of ribosomal DNA (rDNA) from 16 species of the genus Culex and one of Lutzia were used to assess their genomic variability and to verify their applicability in the phylogenetic analysis of the group. The distance matrix (uncorrected p-distance) that was obtained revealed intragenomic and intraspecific variation. Because of the intragenomic variability, we selected ITS2 copies for use in distance analyses based on their secondary structures. Neighbour-joining topology was obtained with an uncorrected p-distance. Despite the heterogeneity observed, individuals of the same species were grouped together and correlated with the current, morphology-based classification, thereby showing that ITS2 is an appropriate marker to be used in the taxonomy of Culex.

Key words: Diptera - Culex - ITS2 - rDNA - phylogeny - concerted evolution

Culex Linnaeus is the largest genus of the Culicine with 768 species subdivided into 26 subgenera (Harbach 2011). The Culex genus includes species suspected of being potential vectors for filarial worms and several arboviruses, including the Venezuelan equine encephalitis virus (Weaver et al. 2004) and the West Nile virus (Turell et al. 2001). In the Americas, members of this extensive genus are subdivided into 14 subgenera. The subgenera Melanoconion Theobald and Culex Linnaeus are those of greatest epidemiological importance in the region and include most of the neotropical species. In Brazil, the Saint Louis encephalitis virus has been isolated from Culex (Culex) coronator Dyar and Knab and Culex (Cux.) declarator Dyar and Knab (Vasconcelos et al. 1991). Culex (Cux.) quinquefasciatus Say is the main vector for Wuchereria bancrofti, with active transmission in areas in the Northeast of Brazil (Fontes et al. 1998, 2005). Despite the medical importance of some species of the genus Culex and the great discomfort they cause, little progress has been made in the taxonomy and systematics of the genus. Most Culex mosquito research focuses on the epidemiology of arboviruses and potential vectors (Turell et al. 2001, Weaver et al. 2004) and on the control of species that transmit pathogens to humans

Financial support: FAPESP (05/50225-2 for MTM and 05/53973-0), CNPq (BPP 300351/2008-9 to MAMS)

FTV was a Master's student supported by CAPES

+ Corresponding author:mmarelli@usp.br

Received 23 April 2010

Accepted 4 November 2010 and other vertebrates (Regis et al. 1995, Melo et al. 2009).

The taxonomic history of Culex demonstrates the complexity of the group and the difficulty in differentiating its species using traditional morphological criteria alone. The morphological identification of these mosquitoes is difficult because many species of Culex are morphologically similar (Bram 1967, Williams \& Savage 2009). Furthermore, some Culex species belong to species complexes (Smith \& Fonseca 2004), there are hybrid forms (Humeres et al. 1998, Smith \& Fonseca 2004) and intraspecific variations in established diagnostic characteristics are frequently reported (Rey et al. 2006). Lastly, field-collected adult specimens often lack ornamentation characteristics, making their identification difficult based on morphology alone (Knight \& Nayar 2004). There are few taxonomic studies for groups of Culex. In Bram's (1967) revision of neotropical species of Culex and the subgenus Culex, a description of a new species, a re-description of several species and identification keys for the male genitalia and fourth instar larval characteristics are included. In another study, Tanaka (2003) elevated the subgenus Lutzia Theobald to the status of genus of the Culicine tribe.

Accurate species identification is fundamental for ecological, biological and epidemiological studies. Diagnosis based on traditional methods, including the external structures of the male genitalia, allows for initial identification that can be further tested using molecular techniques. Thus, many species previously considered unique and homogeneous turn out to consist of other isomorphic forms (Forattini 2002). Ribosomal DNA (rDNA) sequences have been used widely in mosquito taxonomy and phylogenetic analyses (Walton et al. 1999, Sallum et al. 2002, Marrelli et al. 2005). Due 
to the concerted evolution mechanism, multiple copies of rDNA tend to homogenize, maintaining a low level of intraspecific and intragenomic variation. Thus, rDNA transcribed spaces (ITS) sequences prove useful for solving evolutionary relationships at different taxonomic levels, including recently diverged taxa. It is also helpful for solving problems associated with the identification of morphologically similar species by polymerase chain reaction (PCR) (Collins \& Paskewitz 1996, Djadid et al. 2007). The first molecular approach for investigating the phylogenetic relationships between 14 species of four subgenera of the Culex genus was carried out by Miller et al. (1996), using both ITS1 and ITS2 rDNA. The authors found sequence heterogeneity for both ITSs between species and, in some cases, between individual mosquitoes. Importantly, among the species included in Miller et al. (1996), two were analyzed in our study. Furthermore, a phylogenetic analysis of the Vomerifer and Pedroi groups of the Spissipes Section of Culex (Melanoconion) also employed ITS2 sequences (Navarro \& Weaver 2004).

To gain a better understanding of group relationships, we investigated the intragenomic, intraspecific and interspecific variation among 16 mosquito species of the Culex genus, including those belonging to the subgenera, Culex, Microculex Theobald, Melanoconion, Phenacomyia Harbach and Peyton and one taxon of the genus Lutzia. The main objective of this study was to establish the taxonomic relationships within the Culex genus in the neotropics, in order to test the phylogenetic placement of the subgenera Phenacomyia and Lutzia relative to Culex.

\section{MATERIALS AND METHODS}

Mosquitoes - The species sampled for this study, specimen abbreviations, details about field collections and GenBank/EMBL clone accessions are shown in Supplementary data. The mosquitoes were collected from 2006-2008 in 14 localities in the four following Brazilian states: São Paulo (SP), Espírito Santo (ES), Rio Grande do Sul and Paraná. Most species were collected in their immature larval or pupal stage, though some adults were captured in the field. The immature specimens were reared in the laboratory to the adult stage. Male genitalia, larval and/or pupal exuviae, or all three, were mounted on Canada balsam on microscope slides and deposited for record purposes in the Entomological Collection of the School of Public Health of the University of São Paulo, Brazil. ITS2 sequences were characterized from adult males.

DNA extraction and amplification - Genomic DNA was extracted from specimens that were initially preserved in $100 \%$ ethanol at room temperature in the field and subsequently frozen at $-80^{\circ} \mathrm{C}$. DNA was extracted from the specimens following the tissue DNA extraction protocol provided with the DNeasy Blood \& Tissue Kit (QIAGEN, Crawley, UK). The DNA extracted from all samples was preserved at $-80^{\circ} \mathrm{C}$ for future use. The PCR amplification of the ITS2 region was carried out using the primers 5.8SF (5'-ATCACTCGGCTCGTGGATCG-3') and 28SR (5'-ATGCTTAAATTTAGGGGGTAGTC-3') (Djadid et al. 2007). PCR products were amplified in a $25 \mu \mathrm{L}$ reaction mix containing 3-10 $\mu \mathrm{L}$ of genomic DNA (1st elution), $2.5 \mu \mathrm{L}$ of 10X PCR buffer (Fermentas), 1.25 $\mathrm{mM} \mathrm{MgCl}, 0.12 \mathrm{mM}$ of each dNTP (Fermentas), 10 picomols of each primer, $8 \%$ dimethyl sulfoxide, $1.25 \mathrm{U}$ of Taq DNA polymerase (Fermentas) and [DNase/RNasefree distilled water (Invitrogen)]. PCRs were performed at $94^{\circ} \mathrm{C}$ for $2 \mathrm{~min}, 34$ cycles at $94^{\circ} \mathrm{C}, 55^{\circ} \mathrm{C}$ and $72^{\circ} \mathrm{C}$ for $30 \mathrm{~s}$, followed by a final extension step at $72^{\circ} \mathrm{C}$ for $20 \mathrm{~min}$. PCR products were visualized by ethidium bromide staining after electrophoresis in a $1.5 \%$ agarose gel. The products were purified using isopropanol and electrophoresed again to quantify DNA.

DNA cloning and sequencing - Amplicons containing the ITS2 region and some of the flanking $5.8 \mathrm{~S}$ and $28 \mathrm{~S}$ genes were cloned using the InsTAclone ${ }^{\mathrm{TM}}$ PCR Cloning Kit (Fermentas) and Escherichia coli strain DH5 $\alpha$ (Invitrogen) for transformation. The cloned sequences were extracted by PCR colony using the same protocol as ITS2 PCR, but using vector plasmid primers M13/pUC F (5'-GTAAAACGACGGCCAGT-3') and M13/pUC R (5'-CAGGAAACAGCTATGAC-3'). The clones were sequenced in both directions, using the same vector plasmid primers with a Big Dye ${ }^{\circledR}$ Terminator version 3.1 Cycle Sequencing Kit (PE Applied Biosystems, Warrington, England) in an ABI PRISM ${ }^{\circledR}$ 3100 automated sequencer (Genetic Analyzer/HITACH, Applied Biosystems, Foster City, CA, USA).

Sequence analysis - All ITS2 sequences obtained, including parts of the $5.8 \mathrm{~S}$ and $28 \mathrm{~S}$ genes, were analyzed and edited using Chromas Lite version 2.01 software (Technelysium Pty Ltd 2007). The ITS2 sequences obtained were compared with sequences available in the GenBank/EMBL database, using the Basic Local Alignment Search Tool (Zhang et al. 2000). The ITS2 sequences were annotated using the ITS2 annotation tool (Keller et al. 2009). Nucleotide sequences were aligned using the multiple alignment program CLUSTALX version 2.0 (Larkin et al. 2007) with a gap opening penalty of 10 and a gap extension penalty of 5. ITS2 sequences of three species available in GenBank were used as an out-group, including Psorophora (Janthinosoma) ferox (Von Humboldt) (M95129), Aedes (Aedimorphus) vexans Meigen (EF539857) and Aedes (Stegomyia) aegypti Linnaeus (AY512670). Because of the large interspecific variability, we edited the alignment using the program MacClade version 4.3 (Maddison \& Maddison 2000). We used the proposed ITS secondary structure to minimize ambiguities in the sequence alignments.

Selection of clones by secondary structure - At least two sequences of each individual were used to obtain the secondary structures with the Model tool available in the ITS2 database (Schultz et al. 2006, Selig et al. 2008). Given the interspecific variability in the spatial pattern from structures, especially between different subgenera, we clustered one sequence of each species with known structures with three sequences of each 
species with unknown structures. We then checked each cluster for the presence of sequences with assigned structures. Thus, the assigned structure that resulted in the best alignment with the template sequences was selected as a model for transferring the structure to the homologous sequences within all 144 clones. To ensure high prediction performance, the structure was transferred only when more than $75 \%$ of all base pairs (bp) of each helix could be used. Only clones with a highquality model (> 75\%) were selected.

Sequence alignment and distance analysis - Selected sequences were aligned in CLUSTALX version 2.0 (Larkin et al. 2007). The alignment of the ITS2 sequences, excluding $5.8 \mathrm{~S}$ and $28 \mathrm{~S}$, was edited manually in MacClade version 4.0 (Maddison \& Maddison 2000). The divergences between the ITS2 sequences were accessed by distance matrices, produced in Molecular Evolutionary Genetics Analysis version 4.0 (Tamura et al. 2007). A neighbour-joining (NJ) (Saitou \& Nei 1987) topology was generated with an uncorrected p-distance in Phylogenetic Analysis Using Parsimony* (PAUP*) version 4.0 (Swofford 2003). Statistical support for the branches was estimated by bootstrap analysis with 1,000 replicates.

\section{RESULTS}

We sequenced ITS2 PCR products from 31 individuals belonging to the subgenera Microculex, Melanoconion, Culex and Phenocomyia and one of the genus Lutzia (Supplementary data). The number of clones sequenced per individual ranged from 3-7, with 144 sequences obtained in total. An alignment of 93 different sequences is shown in Supplementary data. The length of ITS2 fragments, including $41 \mathrm{bp}$ of the final portion of the ribosomal $5.8 \mathrm{~S}$ gene and $41 \mathrm{bp}$ of the initial portion of the $28 \mathrm{~S}$ of rDNA, ranged from 281$421 \mathrm{bp}$ in Culex (Microculex) imitator Theobald (imit 1) and Cux. (Cux.) quinquefasciatus (quin 1), respectively. The GenBank/EMBL accessions are shown in Supplementary data.

Intragenomic variation - Of the 31 specimens analyzed only nine (moll 2, bidens, nigri 2, decl 1, dyius, ybarmis, caud 1, bigoti 1 and bigoti 2) showed no variation in the length of cloned fragments within each individual. However, of these, only clones derived from Culex (Cux.) mollis Dyar and Knab (moll 2) showed no intragenomic variation. Differences in sequence length between clones were mainly due to insertions or deletions (indels) in ITS2 microsatellite repeat regions. There were no indels in either $5.8 \mathrm{~S}$ or $28 \mathrm{~S}$. However, in the ITS2, clones from Culex (Cux.) dolosus Lynch Arribalzaga (dolo 2) showed differences of up to $16 \mathrm{bp}$. Details regarding the number of clones sequenced, the variants from each individual selected using the secondary structure, the length of ITS2 only (excluding the $5.8 \mathrm{~S}$ and $28 \mathrm{~S}$ flanking regions) and the mean uncorrected p-distance between clones are shown in Table I.
Intraspecific variation - Details of intraspecific variation, the number of specimens per species, the length of the ITS2 region (excluding the flanking regions $5.8 \mathrm{~S}$ and $28 \mathrm{~S}$ ), the number of clones selected using the secondary structure, the mean uncorrected $\mathrm{p}$-distance and the number of variants of each species are shown in Table II. Lutzia (Lut.) bigoti had the lowest average divergence of all selected sequences $(0.3 \%$ for all clones, $0.4 \%$ for variants) and Cux. (Mcx.) imitator had the highest average divergence $(3.8 \%$ for all of the selected clones, $5 \%$ for variants). In the distance matrix, with uncorrected p-distance made by selecting and grouping only variations per individual, there was greater divergence $(7.1 \%)$ between the clones of specimens of Cux. (Mcx.) imitator from SP (imit 2) and ES (imit 1). Culex (Mel.) caudelli (caud 1 and caud 2) showed a distance of $1.4 \%$ and the other distances between individuals of the same species were below $0.7 \%$ (distance matrix not shown).

Interspecific variation - Considering only the ITS2 region, the species of subgenus Microculex showed the shortest length sequences (199-213 bp), while species of subgenus Culex presented the largest fragments (277-339 bp). The length ranged from 205-213 bp in Melanoconion, from 268-276 bp in Phenacomyia and from 276-278 bp in Lut. bigoti. The range of guanine-cytosine contents of ITS2 variants selected by secondary structure was as follows: subgenus Microculex (50.2-50.3\%), Melanoconion (45.4-50.9\%), Culex (52.8-57.5\%), Phenacomyia (50.6$53 \%$ ) and Lutzia (55.4-55.8\%). According to the data from the distance matrix with uncorrected $\mathrm{p}$-distance between variants of each species (matrix not shown), the shortest distance $(0.5 \%)$ in different species was observed between Cux. (Cux.) declarator Dyar and Knab and Culex (Cux.) bidens Dyar and between Cux. (Cux.) coronator and Culex (Cux.) usquatus. In the subgenus Melanoconion, the shortest distance was between Culex (Mel.) ybarmis and Culex (Mel.) aliciae (0.9\%).

NJ topology - The identification of homologous sites and manual editing of the sequence alignment was difficult because there were many indels and nucleotide substitutions in the sequences. It was therefore not possible to produce a phylogenetic tree by the Maximum Parsimony method, using PAUP* version 4.0. Consequently, only the NJ topology was generated to examine the variability between cloned sequences.

In NJ topology, within the subgenus Culex, Culex nigripalpus + Culex chidesteri Dyar, Cux. declarator + Cux. bidens and Cux. mollis + Cux. dolosus formed wellsupported groups by bootstrap values, which were $100 \%$ for the first two groups and $97 \%$ for the latter. The cluster of complex coronator species (Cux. usquatus and Cux. coronator) was also supported by a high bootstrap value (100\%). Only Cux. quinquefasciatus was not grouped with all other taxa of the subgenus, occupying a position as a neighbouring group to the others. Lutzia and the subgenus, Phenacomyia, were placed within the Culex subgenus. Subgenera Melanoconion and Microculex formed two distinct but closely related groups. 
TABLE I

Intragenomic variability between the internal transcribed sequences (ITS2) sequences of all clones and variants, both selected by the secondary structure in the same individual

\begin{tabular}{|c|c|c|c|c|c|}
\hline \multirow[b]{2}{*}{ Specimens } & \multirow[b]{2}{*}{$\begin{array}{l}\text { ITS2 length } \\
\text { (bp) }\end{array}$} & \multicolumn{2}{|c|}{ All clones selected } & \multicolumn{2}{|c|}{ Variants selected } \\
\hline & & $\begin{array}{l}\text { Clones } \\
\text { (n) }\end{array}$ & $\begin{array}{l}\text { Mean uncorrected } \\
\text { p-distance }\end{array}$ & $\begin{array}{l}\text { Variants } \\
\text { (n) }\end{array}$ & $\begin{array}{l}\text { Mean uncorrected } \\
\text { p-distance }\end{array}$ \\
\hline coro 1 & $304-302$ & 6 & 0.019 & 5 & 0.023 \\
\hline coro 2 & $298-304$ & 3 & 0.002 & 2 & 0.003 \\
\hline coro 3 & $300-306$ & 5 & 0.022 & 5 & 0.024 \\
\hline usqua 1 & $294-297$ & 5 & 0.007 & 5 & 0.007 \\
\hline usqua 2 & $294-298$ & 5 & 0.007 & 2 & 0.009 \\
\hline moll 1 & $281-285$ & 5 & 0.009 & 4 & 0.007 \\
\hline moll 2 & 292 & 5 & 0 & 1 & 0 \\
\hline bidens 1 & 277 & 4 & 0.004 & 3 & 0.005 \\
\hline chid 1 & $286-288$ & 5 & 0.009 & 4 & 0.009 \\
\hline dolo 1 & $283-285$ & 5 & 0.011 & 2 & 0.018 \\
\hline dolo 2 & $268-284$ & 6 & 0.011 & 2 & 0.019 \\
\hline nigri 1 & $277-280$ & 5 & 0.014 & 5 & 0.014 \\
\hline nigr 2 & 280 & 5 & 0.002 & 2 & 0.004 \\
\hline quin 1 & $336-339$ & 5 & 0.007 & 4 & 0.009 \\
\hline quin 2 & $324-335$ & 4 & 0.011 & 3 & 0.015 \\
\hline quin 3 & $332-338$ & 6 & 0.009 & 4 & 0.013 \\
\hline quin 4 & $333-336$ & 5 & 0.009 & 2 & 0.015 \\
\hline decl 1 & $283-287$ & 3 & 0.014 & 2 & 0.021 \\
\hline imit 1 & 199 & 2 & 0 & 1 & 0 \\
\hline imit 2 & $211-213$ & 5 & 0 & 2 & 0 \\
\hline zete 1 & $206-207$ & 5 & 0.002 & 3 & 0.003 \\
\hline aliciae 1 & $208-212$ & 3 & 0.016 & 3 & 0.016 \\
\hline dyius 1 & 205 & 5 & 0.006 & 2 & 0.010 \\
\hline ybarmis 1 & 218 & 3 & 0.009 & 2 & 0.014 \\
\hline caud 1 & 205 & 5 & 0.029 & 4 & 0.032 \\
\hline caud 2 & 205 & 4 & 0.020 & 2 & 0.040 \\
\hline corni 1 & 279 & 4 & 0.002 & 2 & 0.004 \\
\hline corni 2 & $268-276$ & 3 & 0.007 & 2 & 0.011 \\
\hline bigoti 1 & 276 & 4 & 0.002 & 2 & 0.004 \\
\hline bigot 2 & 278 & 3 & 0.002 & 2 & 0.004 \\
\hline
\end{tabular}

bp: base pairs.

\section{DISCUSSION}

According to the current classification of the Culicine, this tribe includes four genera, Culex, Deinocerites, Galindomyia and Lutzia. The latter was previously considered a subgenus of the genus Culex (Bram 1967) and was elevated to genus by Tanaka (2003). It is interesting to note that in the NJ topology, Lut. bigoti was recovered within the genus Culex (Figure), which thus conflicts with Tanaka's (2003) classification proposal. Navarro and Liria (2000) inferred the phylogenetic relationships between seven subgenera of Culex and Deinocerites by parsimony analysis of the characteristics of the fourth instar larval mouthparts. Parsimony topologies showed 
TABLE II

Intragenomic variability between the internal transcribed sequences (ITS2) sequences of all clones and variants, both selected by the secondary structure in the same species

\begin{tabular}{|c|c|c|c|c|c|}
\hline \multirow[b]{2}{*}{$\begin{array}{l}\text { Species } \\
\text { (number of specimens) }\end{array}$} & \multirow[b]{2}{*}{$\begin{array}{l}\text { ITS2 length } \\
\text { (bp) }\end{array}$} & \multicolumn{2}{|c|}{ All clones selected } & \multicolumn{2}{|c|}{ Variants selected } \\
\hline & & $\begin{array}{l}\text { Clones } \\
\text { (n) }\end{array}$ & $\begin{array}{l}\text { Mean uncorrected } \\
\text { p-distance }\end{array}$ & $\begin{array}{l}\text { Variants } \\
\text { (n) }\end{array}$ & $\begin{array}{l}\text { Mean uncorrected } \\
\text { p-distance }\end{array}$ \\
\hline Culex (Cux.) coronator (3) & 298-306 & 14 & 0.019 & 12 & 0.019 \\
\hline Culex (Cux.) usquatus (2) & $294-298$ & 10 & 0.007 & 7 & 0.010 \\
\hline Culex (Cux.) mollis (2) & $281-285$ & 10 & 0.012 & 5 & 0.011 \\
\hline Culex (Cux.) bidens (1) & 277 & 4 & 0.004 & 3 & 0.005 \\
\hline Culex (Cux.) chidesteri (1) & $286-288$ & 5 & 0.009 & 4 & 0.009 \\
\hline Culex (Cux.) dolosus (2) & $268-285$ & 11 & 0.017 & 4 & 0.020 \\
\hline Culex (Cux.) nigripalpus (2) & $277-280$ & 10 & 0.009 & 7 & 0.012 \\
\hline Culex (Cux.) quinquefasciatus (4) & $324-339$ & 20 & 0.009 & 13 & 0.010 \\
\hline Culex (Cux.) declarator (1) & $283-287$ & 3 & 0.014 & 2 & 0.021 \\
\hline Culex (Mcx.) imitator (2) & $199-213$ & 7 & 0.038 & 3 & 0.050 \\
\hline Culex (Mel.) zeteki (1) & $206-207$ & 5 & 0.002 & 3 & 0.003 \\
\hline Culex (Mel.) aliciae (1) & $208-212$ & 3 & 0.016 & 3 & 0.016 \\
\hline Culex (Mel.) dyius (1) & 205 & 5 & 0.006 & 2 & 0.010 \\
\hline Culex (Mel.) ybarmis (1) & 218 & 3 & 0.009 & 2 & 0.014 \\
\hline Culex (Mel.) caudelli (2) & 205 & 9 & 0.027 & 6 & 0.030 \\
\hline Culex (Phc.) corniger (2) & $268-276$ & 7 & 0.006 & 4 & 0.008 \\
\hline Lutzia (Lut.) bigoti (2) & $276-278$ & 7 & 0.003 & 4 & 0.00 \\
\hline
\end{tabular}

bp: base pairs.

Lutzia in a basal position sharing a sister-group relationship with the clade that includes species of Culex. This result confirmed the classification of Belkin (1962), which treated Lutzia as a specialized lineage that shares a similarity and therefore ancestry with members of the subgenus Culex. Belkin also corroborated the topology obtained by Miller et al. (1996) from their analysis of rDNA sequences. Nevertheless, the conflicting position of Lutzia presented in our study was supported by topologies generated using sequences of the mitochondrial cytochrome oxidase (COI) gene (Demari-Silva et al. 2011). The results of our molecular analysis employing the ITS2 and the COI sequence data do not support a genus position for Lutzia. The NJ topology (Figure) recovered the subgenus Phenacomyia embedded within a group that includes members of the subgenus Culex (90\% bootstrap support).

As with Lutzia, our results do not support the current status of Phenacomyia as a subgenus of Culex, as was proposed by Harbach and Peyton (1992). The placement of Phenacomyia within the subgenus Culex also disagrees with the topology of Navarro and Liria (2000), in which Phenacomyia is placed in a basal position relative to the clade that includes species of the subgenus Culex. Again, analyses of the ITS2 sequence data were corroborated by analysis of the COI mtDNA (Demari-Silva et al. 2011). Furthermore, the results of the ITS2 sequence data showed that in the current classification, the subgenus Culex is paraphyletic because it excludes Phenacomyia.

Species of the subgenera Microculex and Melanoconion formed a monophyletic clade ( $96 \%$ bootstrap support) and these subgenera are clustered in two distinct groups, each supported by a $100 \%$ bootstrap analysis value (Figure). The results of the NJ analysis are in agreement with the current classification of Culex, with individuals of the same species and species complex grouped together. Considering the interspecific variation in ITS2 sequences, species belonging to the Cux. coronator (Cux. usquatus and Cux. coronator) complex formed a clade (Figure) and species with similar morphology (Cux. bidens + Cux. declarator and Cux. nigripalpus + Cux. chidesteri) also clustered. The positioning of Cux. (Cux.) quinquefasciatus as a sister group of the clade, which includes the others species of Culex, is similar to the topology obtained by Navarro and Liria (2000) based on the morphological characteristics of the larval maxilla and mandibula. The authors analyzed the phy- 


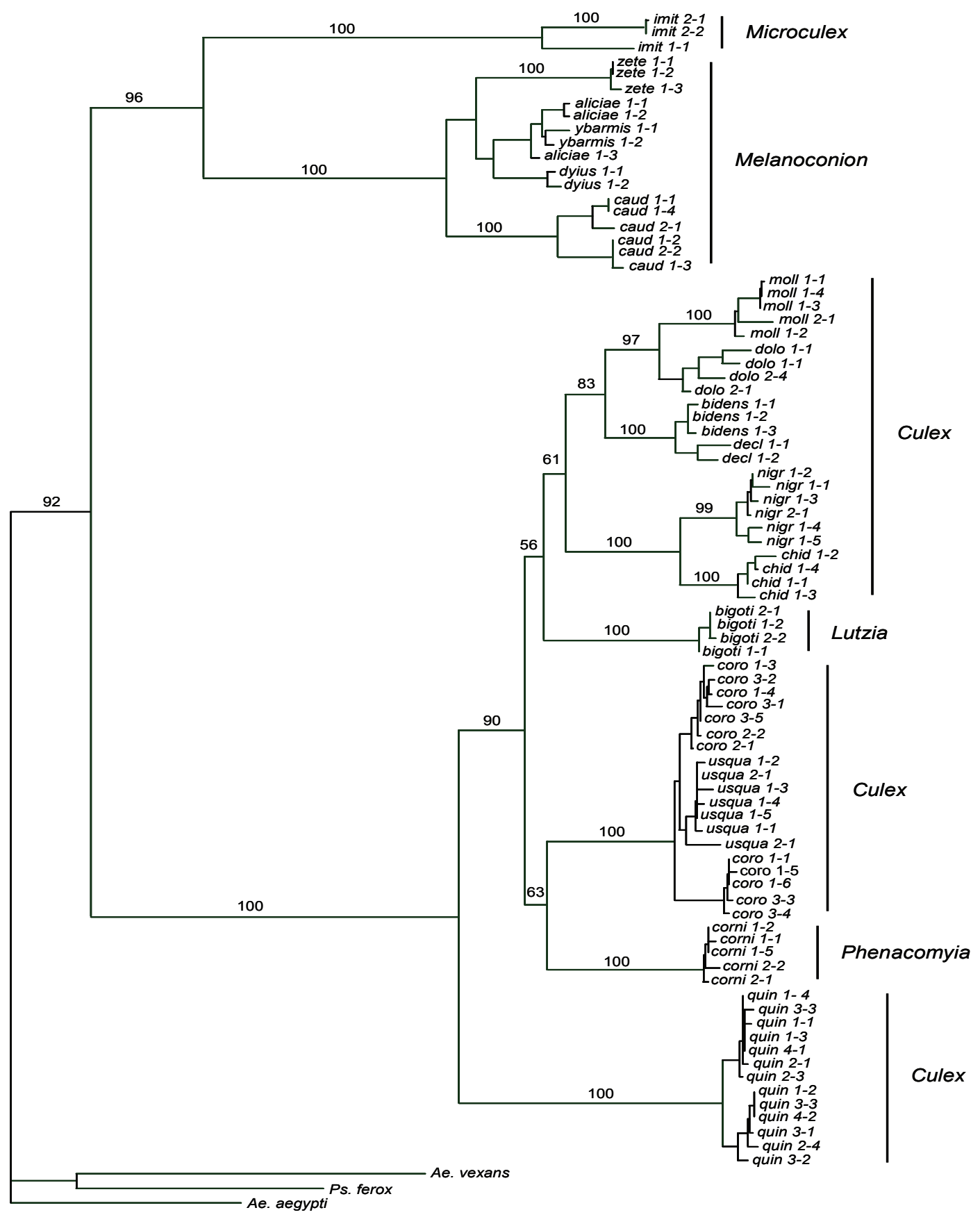

Distance tree generated with the variants selected by internal transcribed sequences secondary structure (specimen codes-clone numbers). Only the model structures with high-quality $(>75 \%)$ in the transfer helices, using "Homology Modeling" tool were selected. The topology was constructed by neighbor-joining method, uncorrected p-distance, bootstrap confidence levels (\%) from 1,000 replications and rooted with Aedes vexans (EF539857), Psorophora ferox (M95129) and Aedes aegypti (AY512670) sequences of GenBank/EMBL.

logenetic relationships of 18 species from eight genera of the tribe Culicine, including Cux. quinquefasciatus, Cux. dolosus, Cux. nigripalpus and Cux. coronator for subgenus Culex. In the clade formed by species of these subgenera, Cux. quinquefasciatus is a sister of a clade that includes Cux. dolosus, Cux. nigripalpus and Cux. coronator, which is consistent with the ITS2 NJ topology analysis. Cux. ybarmis and Cux. aliciae of the sub- genus Melanoconion showed the lowest mean p-distance between their clones $(0.9 \%)$. Due to the great morphological similarity and consequent difficulty in differentiating Cux. aliciae from Culex dyius, we expected to find that these two species were related at the molecular level. In this subgenus, dissection and examination of the lateral plate of the aedeagus from a lateral perspective is essential for species identification (Rozeboom 
1950). In Cux. dyius, the lateral plate of the aedeagus is slender with a long, broad, blunt point at an angle in the middle, with a few small teeth at its apex (Lane 1953). In Cux. aliciae, this structure is very similar (Duret 1953). In Cux. ybarmis this structure is different, presenting the apical, dorsal and sterna processes, with its dorsal process curved (Lane 1953).

Cux. imitator, the only species of Microculex analyzed in this study, proved to have the greatest intraspecific divergence (7.1\%) among specimens from SP (imit 2) and ES (imit 1) (data not shown). In addition, morphological variations were observed in the pupal exuviae of specimens from SP and ES, suggesting that the two individuals may belong to different species. The pupa of an individual of Cux. imitator, from the same location as the specimen from ES that was analyzed molecularly, showed typical characteristics of Cux. imitator, including a dark spot on segments II, III and IV and the arrangement pattern of setae 2, 3, 4 and 5 of segment II. The specimen from SP did not have the spot and had another arrangement pattern of its setae (morphological data not shown). Analysis of COI sequences also indicated high intraspecific variation for these specimens (Demari-Silva et al. 2011), thus corroborating the morphological hypothesis that these individuals may belong to different taxa of a species complex. In a phylogenetic analysis of species of the Pedroi and Vomerifer groups of Melanoconion, Navarro and Weaver (2004) used ITS sequence analysis and observed an intraspecific variation of $0-3.3 \%$ between individuals from the same location (Culex pedroi in Venezuela or Cux. pedroi-Peru form in Peru) and $0-4.5 \%$ between those from different locations (Culex vomerifer: Colombia vs. Peru).

The intragenomic and intraspecific variability of clones contradicted the theory of concerted evolution and prevented phylogenetic analysis because the alignment that is a fundamental step for reliability of any evolutionary analysis was compromised. There is a possibility of PCR-induced mutations, which might interfere in the assessment of intragenomic and intraspecific variability because the lack of 3'-5' proofreading ability of the Taq DNA polymerase used in our experiments results in an error rate (mutations per nucleotide per cycle) of approximately 1 in 10,000 bases (Eckert \& Kunkel 1991, Barnes 1994). However, considering that PCR errors are also proportionally related to the length of the PCR products and that approximately 50,000 bases were sequenced in the present study, the interference of PCR-induced mutations in our final conclusions was not significant.

Some aspects of the phenomenon of intragenomic variability remains unclear, but the high intragenomic heterogeneity observed seems to be the result of a comparison between sequences of different clusters undergoing different levels of evolution. Similar results were observed by Miller et al. (1996), who showed heterogeneity between sequences of the same individual in different populations of the Culex pipiens complex, thus invalidating the use of ITS markers for phylogenetic analysis of taxa that exhibit intragenomic variation. However, there was general agreement between the groupings ob- tained in the topologies for species of the genus Culex and the recognition of taxa by morphology. Therefore, in both this study and the previously mentioned work, the trees obtained generally corroborated the traditional taxonomy of taxa, indicating that despite the presence of intragenomic variation, the ITS2 marker seems to be appropriate for solving taxonomic doubts in the group.

\section{REFERENCES}

Barnes WM 1994. PCR amplification of up to 35-kb DNA with high fidelity and high yield from lambda bacteriophage templates. Proc Natl Acad Sci USA 91: 2216-2220.

Belkin JN 1962. The mosquitoes of the South Pacific (Diptera, Culicidae), vol. I, University of California Press, Berkeley and Los Angeles, 545 pp.

Bram RA 1967. Classification of Culex subgenus Culex in the New World (Diptera, Culicidae). Proc US Nat Hist Mus 120: 1-122.

Collins FH, Paskewitz SM 1996. A review of the use of ribosomal DNA (rDNA) to differentiate among cryptic Anopheles species. Insect Mol Biol 5: 1-9.

Demari-Silva B, Vesgueiro FT, Sallum MA, Marrelli MT 2011. Taxonomic and phylogenetic relationships between species of the genus Culex (Diptera: Culicidae) from Brazil inferred from the Cytochrome C Oxidase I mitochondrial gene. J Med Entomol, in press.

Djadid ND, Gholizadeh S, Tafsiri E, Romi R, Gordeev M, Zakeri S 2007. Molecular identification of Paleartic members of Anopheles maculipennis in northern Iran. Malar J 6: 6.

Duret JP 1953. Las especies argentinas de Culex (Melanoconion) (Diptera: Culicidae). Rev Soc Entomol Argent 16: 67-76.

Eckert KA, Kunkel TA 1991. DNA polymerase fidelity and the polymerase chain reaction. PCR Methods Appl 1: 17-24.

Fontes G, Braun RF, Fraiha Neto H, Vieira JB, Padilha SS, Rocha RC, da Rocha EM 2005. Filariose linfática em Belém, estado do Pará, Norte do Brasil e a perspectiva de eliminação. Rev Soc Bras Med Trop 38: 131-136.

Fontes G, Rocha EM, Brito AC, Antunes CM 1998. Lymphatic filariasis in Brazilian urban area (Maceió, Alagoas). Mem Inst Oswaldo Cruz 93: 705-710.

Forattini OP 2002. Culicidologia médica: identificação, biologia e epidemiologia, vol. II, EDUSP, São Paulo, 864 pp.

Harbach RE 2011. Mosquito taxonomic inventory. Culicidae classification. Natural History Museum, London, UK [cited 2009 Nov 11]. Available from: http://mosquito-taxonomic-inventory. info/em/taxonomy/term/6165.

Harbach RE, Peyton EL 1992. A new subgenus of Culex in the Neotropical region (Diptera: Culicidae). Mosq Syst 24: 242-252.

Humeres SG, Almirón WR, Sabattini MS, Gardenal CN 1998. Estimation of genetic divergence and gene flow between Culex pipiens and Culex quinquefasciatus (Diptera: Culicidae) in Argentina. Mem Inst Oswaldo Cruz 93: 57-62.

Keller A, Schleicher T, Schultz J, Müller T, Dandekar T, Wolf M 2009. 5.8S-28S rRNA interaction and HMM-based ITS2 annotation. Gene 430: 50-57.

Knight JW, Nayar JK 2004. Identification of four common Culex (Culex) (Diptera: Culicidae) species from Florida with isoenzyme analysis. Fla Entomol 87: 1-5.

Lane J 1953. Neotropical Culicidae, vol. I, EDUSP, São Paulo, 558 pp.

Larkin MA, Blackshields G, Brown NP, Chenna R, McGettigan 
PA, McWilliam H, Valentin F, Wallace IM, Wilm A, Lopez R, Thompson JD, Gibson TJ, Higgins DG 2007. Clustal W and CLUSTALX version 2.0. Bioinformatics 23: 2947-2948.

Maddison DR, Maddison WP 2000. MacClade 4: analysis of phylogeny and character evolution, Sinauer, Sunderland, $398 \mathrm{pp}$.

Marrelli MT, Floeter-Winter LM, Malafronte RS, Tadei WP, Lourenço-de-Oliveira R, Flores-Mendoza C, Marinotti O 2005. Amazonian malaria vector anopheline relationships interpreted from ITS2 rDNA sequences. Med Vet Entomol 19: 208-218.

Melo AL, Soccol CR, Thomaz-Soccol V, Nogueira M Jr 2009. Evaluation of Bacillus sphaericus bioinsecticide produced with white soybean meal as culture medium for the control of Culex (Culex) quinquefasciatus. Cad Saude Publica 25: 563-569.

Miller BR, Crabtree MB, Savage HM 1996. Phylogeny of fourteen Culex mosquito species, including the Culex pipiens complex, inferred from the internal transcribed spacers of ribosomal DNA. Insect Mol Biol 5: 93-107.

Navarro JC, Liria J 2000. Phylogenetic relationships among eighteen neotropical Culicini species. J Am Mosq Control Assoc 16: $75-85$.

Navarro JC, Weaver SC 2004. Molecular phylogeny of the Vomerifer and Pedroi groups in the Spissipes section of the subgenus Culex (Melanoconion). J Med Entomol 41: 575-581.

Regis L, Silva-Filha MHNL, de Oliveira CMF, Rios EM, da Silva SB, Furtado AF 1995. Integrated control measures against Culex quinquefasciatus, the vector of filariasis in Recife. Mem Inst Oswaldo Cruz 90: 115-119.

Rey JR, O'Meara GF, O'Connell SM, Darsie RF 2006. Variation in the number and position of siphonal setae in Culex quinquefasciatus from Key West and Vero Beach, Florida, USA. J Am Mosq Control Assoc 22: 355-357.

Rozeboom LE 1950. A review of the species of Culex of the subgenus Melanoconion (Diptera: Culicidae). Ann Entomol Soc Am 43: $75-114$.

Saitou N, Nei M 1987. The neighbor-joining method: a new method for reconstructing phylogenetic trees. Mol Biol Evol 4: 406-425.

Sallum MAM, Schultz TR, Foster PG, Aronstein K, Wirtz RA, Wilkerson RC 2002. Phylogeny of Anophelinae (Diptera: $\mathrm{Cu}-$ licidae) based on nuclear ribosomal and mitochondrial DNA sequences. Syst Entomol 27: 361-382.
Schultz J, Müller T, Achtziger M, Seibel PN, Dandekar T, Wolf M 2006. The internal transcribed spacer 2 database: a web server for (not only) low level phylogenetic analyses. Nucleic Acids Res 34: 704-707.

Selig C, Wolf M, Müller T, Dandekar T, Schultz J 2008. The ITS2 Database II: homology modelling RNA structure for molecular systematics. Nucleic Acids Res 36: 377-380.

Smith JL, Fonseca DM 2004. Rapid assays for identification of members of the Culex (Culex) pipiens complex, their hybrids, and other sibling species (Diptera: Culicidae). Am J Trop Med Hyg 70: 339-345.

Swofford DL 2003. PAUP*. Phylogenetic analysis using parsimony (*and other methods), version 4.01b, Sinauer Associates, Sunderland, Massachusets.

Tamura K, Dudley J, Nei M, Kumar S 2007. MEGA 4: Molecular Evolutionary Genetics Analysis (MEGA) software version 4.0. Mol Biol Evol 24: 1596-1599.

Tanaka K 2003. Studies on the pupal mosquitoes of Japan. Genus Lutzia, with establishment of two new subgenera, Metalutzia and Insulalutzia (Diptera, Culicidae). Syst Entomol 9: 159-169.

Technelysium Pty Ltd 2007. [cited 2009 Oct 10]. Chromas lite version 2.01. Available from: http://www.technelysium.com.au/ chromas_lite.html.

Turell MJ, O’Guinn ML, Dohm DJ, Jones JW 2001. Vector competence of North American mosquitoes (Diptera: Culicidae) for West Nile Virus. J Med Entomol 38: 130-134.

Vasconcelos PFC, Travassos-da-Rosa JFS, Travassos-da-Rosa APA, Dégallier N, Pinheiro FP, Sá-Filho GC 1991. Epidemiologia das encefalites por arbovírus na Amazônia brasileira. Rev Inst Med Trop Sao Paulo 33: 465-476.

Walton C, Sharpe RG, Pritchard SJ, Thelwell NJ, Butlin RK 1999. Molecular identification of mosquito species. Biol J Linn Soc 68: 241-256.

Weaver SC, Ferro C, Barrera R, Boshell J, Navarro JC 2004. Venezuelan equine encephalitis. Annu Rev Entomol 49: 141-174.

Williams MR, Savage HM 2009. Identification of Culex (Melanoconion) species of the United States using female cibarial armature (Diptera: Culicidae). J Med Entomol 46: 745-752.

Zhang Z, Schwartz S, Wagner L, Miller W 2000. A greedy algorithm for aligning DNA sequences. J Comput Biol 7: 203-214. 
TABLE

Species studied, specimen codes, localities, geographical coordinates and GenBank/EMBL accessions of clones

\begin{tabular}{|c|c|c|c|c|c|}
\hline Species & Specimens & Sex & Localities & Coordinates & GenBank accessions \\
\hline \multirow[t]{3}{*}{ Culex (Cux.) coronator Dyar and Knab } & coro 1 & $\widehat{0}$ & Campos do Jordão (SP) & $22^{\circ} 45^{\prime} 50^{\prime \prime} \mathrm{S} 45^{\circ} 30^{\prime} 87^{\prime \prime} \mathrm{W}$ & GU299736-GU299740 \\
\hline & coro 2 & $\widehat{o}$ & Linhares (ES) & $19^{\circ} 20.917^{\prime} \mathrm{S} 40^{\circ} 07.103^{\prime} \mathrm{W}$ & GU299741-GU299742 \\
\hline & coro 3 & $\hat{\sigma}$ & Aparecida do Norte (SP) & $22^{\circ} 50^{\prime} 34.4 ” \mathrm{~S} 45^{\circ} 14^{\prime} 45^{\prime \prime} \mathrm{W}$ & GU299743-GU299747 \\
\hline \multirow[t]{2}{*}{ Culex (Cux.) usquatus Dyar } & usqua 1 & $\hat{0}$ & Pariquera-Açu (SP) & $24^{\circ} 43.975^{\prime} \mathrm{S} 47^{\circ} 49.502^{\prime} \mathrm{W}$ & GU299731-GU299735 \\
\hline & usqua 2 & 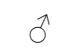 & Pariquera-Açu (SP) & $24^{\circ} 43.975^{\prime} \mathrm{S} 47^{\circ} 49.502^{\prime} \mathrm{W}$ & GU299729-GU299730 \\
\hline \multirow[t]{2}{*}{ Culex (Cux.) mollis Dyar and Knab } & moll 1 & $\hat{\sigma}$ & Pariquera-Açu (SP) & $24^{\circ} 43.975^{\prime} \mathrm{S} 47^{\circ} 49.502^{\prime} \mathrm{W}$ & GU299706-GU299709 \\
\hline & moll 2 & $\hat{O}$ & Pariquera-Açu (SP) & $24^{\circ} 43.975^{\prime} \mathrm{S} 47^{\circ} 49.502^{\prime} \mathrm{W}$ & GU299705 \\
\hline Culex (Cux.) chidesteri Dyar & chid 1 & 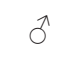 & Pindamonhangaba (SP) & $22^{\circ} 57^{\prime} 35.1 ” \mathrm{~S} 45^{\circ} 27^{\prime} 08.6^{\prime \prime} \mathrm{W}$ & GU299725-GU299728 \\
\hline \multirow[t]{2}{*}{ Culex (Cux.) dolosus Lynch Arribalzaga } & dolo 1 & $\hat{\sigma}$ & Pindamonhangaba (SP) & $22^{\circ} 57^{\prime} 35.1 ” \mathrm{~S} 45^{\circ} 27^{\prime} 08.6$ "W & GU299710-GU299711 \\
\hline & dolo 2 & $\hat{\sigma}$ & Pindamonhangaba (SP) & $22^{\circ} 57^{\prime} 35.1 " \mathrm{~S} 45^{\circ} 27^{\prime} 08.6$ "W & GU299712-GU299713 \\
\hline \multirow[t]{2}{*}{ Culex (Cux.) nigripalpus Theobald } & nigri 1 & $\hat{0}$ & Pariquera-Açu (SP) & $24^{\circ} 43.975^{\prime} \mathrm{S} 47^{\circ} 49.502^{\prime} \mathrm{W}$ & GU299719-GU299723 \\
\hline & nigri 2 & $\hat{\sigma}$ & Pariquera-Açu (SP) & $24^{\circ} 43.975^{\prime} \mathrm{S} 47^{\circ} 49.502^{\prime} \mathrm{W}$ & GU299724 \\
\hline \multirow[t]{4}{*}{ Culex (Cux.) quinquefasciatus Say } & quin 1 & q & Pariquera-Açu (SP) & $24^{\circ} 43.975^{\prime} \mathrm{S} 47^{\circ} 49.502^{\prime} \mathrm{W}$ & GU299748-GU299751 \\
\hline & quin 2 & 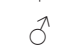 & Pariquera-Açu (SP) & $24^{\circ} 43.975^{\prime} \mathrm{S} 47^{\circ} 49.502^{\prime} \mathrm{W}$ & GU299752-GU299754 \\
\hline & quin 3 & $\hat{0}$ & Bento Gonçalves (RS) & $29^{\circ} 09^{\prime} 28.90 ” \mathrm{~S} 51^{\circ} 30^{\prime} 43.55^{\prime \prime} \mathrm{W}$ & GU299755-GU299758 \\
\hline & quin 4 & 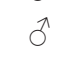 & Bento Gonçalves (RS) & 2909’28.90”'S 51³0’43.55”W & GU299759-GU299760 \\
\hline Culex (Cux.) declarator Dyar and Knab & decl 1 & $\hat{0}$ & Pariquera-Açu (SP) & $24^{\circ} 43.975^{\prime} \mathrm{S} 47^{\circ} 49.502^{\prime} \mathrm{W}$ & GU299717-GU299718 \\
\hline Culex (Cux.) bidens Dyar & bidens 1 & $\hat{\sigma}$ & Aparecida do Norte (SP) & $22^{\circ} 50^{\prime} 34.4^{\prime \prime} \mathrm{S} 45^{\circ} 14^{\prime} 45^{\prime \prime} \mathrm{W}$ & GU299714-GU299716 \\
\hline \multirow[t]{2}{*}{ Culex (Mcx.) imitator Theobald } & imit 1 & $\hat{\sigma}$ & Santa Teresa (ES) & $19^{\circ} 55^{\prime} 54.46^{\prime} \mathrm{S} 40^{\circ} 35^{\prime} 41.61^{\prime \prime} \mathrm{W}$ & GU299677 \\
\hline & imit 2 & 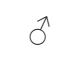 & Pindamonhangaba (SP) & $22^{\circ} 57^{\prime} 35.1 ” S 45^{\circ} 27^{\prime} 08.6 ” \mathrm{~W}$ & GU299678-GU299679 \\
\hline Culex (Mel.) zeteki Dyar & zetk 1 & q & Pariquera-Açu (SP) & $24^{\circ} 43.975^{\prime} \mathrm{S} 47^{\circ} 49.502^{\prime} \mathrm{W}$ & GU299680-GU299682 \\
\hline Culex (Mel.) aliciae Duret & aliciae 1 & $\hat{0}$ & Pariquera-Açu (SP) & $24^{\circ} 43.975^{\prime} \mathrm{S} 47^{\circ} 49.502^{\prime} \mathrm{W}$ & GU299683-GU299685 \\
\hline Culex (Mel.) dyius Root & dyius 1 & $\hat{\sigma}$ & Linhares (ES) & $19^{\circ} 20.917^{\prime} \mathrm{S} 40^{\circ} 07.103^{\prime} \mathrm{W}$ & GU299686-GU299687 \\
\hline Culex (Mel.) ybarmis Dyar & ybarmis 1 & $\hat{\jmath}$ & Linhares (ES) & $19^{\circ} 20.917^{\prime} \mathrm{S} 40^{\circ} 07.103^{\prime} \mathrm{W}$ & GU299688-GU299689 \\
\hline \multirow[t]{2}{*}{ Culex (Mel.) caudelli (Dyar \& Knab) } & caud 1 & $\hat{\sigma}$ & Pariquera-Açu (SP) & $24^{\circ} 43.975^{\prime} \mathrm{S} 47^{\circ} 49.502^{\prime} \mathrm{W}$ & GU299690-GU299693 \\
\hline & caud 2 & $\hat{\sigma}$ & Pariquera-Açu (SP) & $24^{\circ} 43.975^{\prime} \mathrm{S} 47^{\circ} 49.502^{\prime} \mathrm{W}$ & GU299694-GU299695 \\
\hline \multirow[t]{2}{*}{ Culex (Phc.) corniger Theobald } & corni 1 & $\hat{0}$ & Pariquera-Açu (SP) & $24^{\circ} 43.975^{\prime} \mathrm{S} 47^{\circ} 49.502^{\prime} \mathrm{W}$ & GU299700-GU299702 \\
\hline & corni 2 & $\hat{\sigma}$ & Pariquera-Açu (SP) & $24^{\circ} 43.975^{\prime} \mathrm{S} 47^{\circ} 49.502^{\prime} \mathrm{W}$ & GU299703-GU299704 \\
\hline \multirow[t]{2}{*}{ Lutzia (Lut.) bigoti (Bellardi) } & bigoti 1 & q & São Paulo (SP) & $23^{\circ} 26^{\prime} 12.44 ” S 46^{\circ} 38^{\prime} 05.099^{\prime \prime} \mathrm{W}$ & GU299696-GU299697 \\
\hline & bigoti 2 & q & S. José dos Pinhais (PR) & $25^{\circ} 33^{\prime} 14.48^{\prime \prime S} 49^{\circ} 14^{\prime} 08.69^{\prime \prime} \mathrm{W}$ & GU299698-GU299699 \\
\hline
\end{tabular}

ES: Espírito Santo; PR: Paraná; RS: Rio Grande do Sul; SP: São Paulo. 